\title{
Antimicrobial and Antioxidant Activities of Plants from Northeast of Mexico
}

\author{
Ricardo Salazar-Aranda, Luis Alejandro Pérez-López, Joel López-Arroyo, \\ Blanca Alicia Alanís-Garza, and Noemí Waksman de Torres
}

Departamento de Química Analítica, Facultad de Medicina, U.A.N.L. Monterrey, P.O. Box 2316,
Sucursal Tecnológico, 64841, N. L. México, Mexico

Correspondence should be addressed to Noemí Waksman de Torres, nwaksman@fm.uanl.mx

Received 5 March 2009; Accepted 21 July 2009

Copyright (๑) 2011 Ricardo Salazar-Aranda et al. This is an open access article distributed under the Creative Commons Attribution License, which permits unrestricted use, distribution, and reproduction in any medium, provided the original work is properly cited.

\begin{abstract}
Traditional medicine has a key role in health care worldwide. Obtaining scientific information about the efficacy and safety of the plants from our region is one of the goals of our research group. In this report, 17 plants were selected and collected in different localities from northeast Mexico. The dried plants were separated into leaves, flowers, fruit, stems, roots and bark. Each part was extracted with methanol, and 39 crude extracts were prepared. The extracts were tested for their antimicrobial activity using three Gram-negative bacterial strains (Pseudomonas aeruginosa, Klebsiella pneumoniae and Acinetobacter baumannii), three Grampositive bacterial strains (Enterococcus faecalis and two Staphylococcus aureus strains), and seven clinically isolated yeasts (Candida albicans, C. krusei, C. tropicalis, C. parapsilosis and C. glabrata); their antioxidant activity was tested using a DPPH free radical assay. No activity against Gram-negative bacteria was observed with any extract up to the maximum concentration tested, $1000 \mu \mathrm{g} \mathrm{ml}{ }^{-1}$. We report here for the first time activity of Ceanothus coeruleus against $S$. aureus (flowers, minimal inhibitory concentration (MIC) $125 \mu \mathrm{g} \mathrm{ml}^{-1}$ ), C. glabrata (MICs $31.25 \mu \mathrm{g} \mathrm{ml}^{-1}$ ) and C. parapsilosis (MICs between 31.25 and $125 \mu \mathrm{g} \mathrm{ml}^{-1}$ ); Chrysanctinia mexicana against C. glabrata (MICs $31.25 \mu \mathrm{g} \mathrm{ml}^{-1}$ ); Colubrina greggii against E. faecalis (MICs $250 \mu \mathrm{g} \mathrm{ml}^{-1}$ ) and Cordia boissieri against $C$. glabrata (MIC $125 \mu \mathrm{g} \mathrm{ml}^{-1}$ ). Furthermore, this is the first report about antioxidant activity of extracts from Ceanothus coeruleus, Chrysanctinia mexicana, Colubrina greggii and Cyperus alternifolius. Some correlation could exist between antioxidant activity and antiyeast activity against yeasts in the species Ceanothus coeruleus, Schinus molle, Colubrina greggii and Cordia boissieri.
\end{abstract}

\section{Introduction}

The plant kingdom has been the best source of remedies for curing a variety of disease and pain. This is why medicinal plants have played a key role in the worldwide maintenance of health. Traditional herbal medicine is intimately related to the Mexican popular culture; its use has origins based on ancestral knowledge. Natural products of higher plants are an important source of therapeutic agents; therefore, many research groups are currently screening the different biological activities of plants [1-3].

Mexico has an extensive variety of plants; it is the fourth richest country worldwide in this aspect. Some 25000 species are registered, and it is thought that there are $\sim 30000$ not yet described [4]. In particular, the northeast of Mexico, with its semiarid climate, has a great number and variety of wild plants grown under extreme climatic conditions [4]. It is well known that the constituents of medicinal herbs can vary greatly as a result of genetic factors, climate, soil quality and other external factors [5], particularly the semiarid climate from northeast of México causes the production of secondary metabolites different from those found in the same species grown under less extreme conditions.

In the course of our investigations, we have found that several plants from northwest Mexico possess interesting biological activities and could be a source of interesting new secondary metabolites [6-10].

The aim of this work was to investigate the antimicrobial and antioxidant properties of some wild plants grown in northeast Mexico used in the traditional medicine to treat infections or general ailments. In the current study, 39 extracts prepared from 17 plants belonging to different 
genera were submitted to antibacterial and antifungal assays using a microdilution method and to a test of antioxidant activity using the free radical scavenging activity of 1,1-diphenyl-2-picrylhydrazyl (DPPH) using both thinlayer chromatography (TLC) and spectrophotometric assay methods.

The activities have been selected because of their great medicinal relevance. It is well known that in past years, infection rates have increased and antibiotic resistance has become an increasing therapeutic problem [11, 12]. In addition a greater interest in the antioxidant activity of plant extracts exists because of free radicals (e.g., reactive oxygen species) that can be responsible for several diseases, for example, heart disease, stroke, arteriosclerosis and cancer, as well as the aging process [13].

\section{Methods}

2.1. Plant Materials. Wild plants were selected based upon their reported traditional use for the treatment of diseases including tuberculosis, fever, cough, hepatitis, rheumatism, skin diseases and respiratory or gastrointestinal infections. Collections were conducted between October 2000 and July 2002 from different regions in the states of Nuevo León and Coahuila (Table 1). Voucher specimens for each plant were deposited in the herbarium of the Facultad de Ciencias Biológicas, Universidad Autónoma de Nuevo León.

2.2. Extraction Procedure. The air-dried plants were separated into leaves, stems, roots, flowers, fruit and bark; each part was treated independently and immediately extracted. Powdered plant material $(100 \mathrm{~g})$ was extracted by direct maceration with methanol $(3 \times 600 \mathrm{ml})$ for 2 hours at room temperature. The extracts were filtered and evaporated to dryness under low pressure at $38^{\circ} \mathrm{C}$. The different extracts were stored at $4^{\circ} \mathrm{C}$ until tested.

2.3. Test Organisms. The following were used as test organisms: Candida albicans (HU501), C. albicans (HU498), C. albicans (HU53), C. krusei (HU168), C. tropicalis (HU166), C. parapsilosis (HU96), C. glabrata (HU84), Pseudomonas aeruginosa, Klebsiella pneumoniae, Acinetobacter baumannii and Enterococcus faecalis (all provided by the Regional Center for Infection Diseases, Faculty of Medicine, UANL). In addition, two Staphylococcus aureus strains: a wild type (ATCC 12598) and an oxacillin-resistant strain (IMSSNL/HE22:01) were also used.

2.4. Susceptibility Screening. Both bacteria and yeast strains were tested using a microdilution assay following the National Committee for Clinical Laboratory Standards (NCCLS) [24, 25], and minimal inhibitory concentration (MIC) values were determined. Bacterial strains were inoculated on Müeller-Hinton agar plates (Becton Dickinson) and were incubated at $37^{\circ} \mathrm{C}$ for 24 hours. Yeast strains were inoculated on Sabouraud agar plates (Becton Dickinson) and were incubated at $37^{\circ} \mathrm{C}$ for 24 hours. Four-five colonies were transferred from each solid culture to saline solution $(3 \mathrm{ml})$ and then the solution was adjusted to $0.5 \mathrm{McF}$ arland standard turbidity. The appropriate working suspension for each microorganism was prepared: a $1: 50$ dilution in Müeller-Hinton broth for bacteria and a 1:50 after 1:20 dilution in RPMI 1640 medium (Sigma-Aldrich) for yeasts, fresh medium recommended by NCCLS, was used in each case $[24,25]$. The extracts were prepared at $4 \mathrm{mg} \mathrm{ml}^{-1}$ in $5 \%$ DMSO in the appropriate fresh liquid medium. Concentrations for each extract ranged from 1000 to $0.5 \mu \mathrm{g} \mathrm{ml}^{-1}$. A $100 \mu \mathrm{l}$ volume of the extract sample was transferred to the first well of each row, and serial 2-fold dilutions were performed; the remaining $100 \mu \mathrm{l}$ was discarded. A $100 \mu \mathrm{l}$ volume of working suspension was added to each well. Seven samples and one antimicrobial drug control, cephalothin or fluconazole $\left(500-0.25\right.$ or $62.5-0.25 \mu \mathrm{g} \mathrm{ml}^{-1}$, resp.), were included in each plate. Three additional wells were used as growth controls where no drug was added, and culture medium was added to two wells. Plates were incubated at $37^{\circ} \mathrm{C}$ for 48 hours, and the growth was visually examined.

\subsection{Determination of Antioxidant Activity}

2.5.1. Scavenging Activity of DPPH Free Radical by TLC. To measure antioxidant activity, DPPH free radical scavenging assay by TLC was used as previously reported [10]. Briefly, $10 \mu \mathrm{l}$ of each extract $\left(1 \mathrm{mg} \mathrm{ml}^{-1}\right.$ in ethanol) was applied to a chromatographic plate. Chromatography was conducted using ethyl acetate : acetic acid : formic acid: water $(100: 11: 11: 27)$ as eluent. The plate was developed using a DPPH solution $\left(2 \mathrm{mg} \mathrm{ml}^{-1}\right.$ in ethanol); $30 \mathrm{~min}$ later, the yellow spots from reduced DPPH were clearly observed against a purple background.

2.5.2. Scavenging Activity of DPPH Free Radical by Spectrophotometry. Assay of DPPH scavenging activity by spectrophotometry was conducted according to Leu et al. [3], with some modifications. First, the extracts were redissolved in ethanol $\left(1 \mathrm{mg} \mathrm{ml}^{-1}\right)$, and different concentrations (200$0.234 \mu \mathrm{g} \mathrm{ml}^{-1}$ ) of each extract were used. In a total volume of $1 \mathrm{~mL}$, the assay mixture contained $500 \mu \mathrm{l}$ of the extract and $500 \mu \mathrm{l}$ of DPPH $(125 \mu \mathrm{M}$ in ethanol). The assay mixture was shaken and allowed to stand at room temperature in darkness for $30 \mathrm{~min}$. The absorbance was then measured at $517 \mathrm{~nm}$ in a DU 7500 spectrophotometer (Beckman Coulter). Quercetin was used as a positive control. The capacity to scavenge the DPPH radical was calculated as follows:

$$
\text { Radical scavenging activity (percent) }=\frac{(A-B)}{A} \times 100 \text {, }
$$

where, $A$ is the absorbance of the negative control (DPPH plus ethanol) and $B$ is the absorbance of the sample (DPPH, ethanol plus sample). The correlation between each concentration and its percentage of scavenging was plotted, and the $\mathrm{EC}_{50}$ was calculated by interpolation. The activity was expressed as $\mathrm{EC}_{50}$ (the effective concentration of each extract that scavenges $50 \%$ of DPPH radicals). 
TABLE 1: List of plants screened.

\begin{tabular}{|c|c|c|c|c|}
\hline Plant & Voucher & Family & Part & Popular use \\
\hline Ceanothus coeruleus Lag. & 024099 & Rhamanceae & $\mathrm{L}, \mathrm{F}, \mathrm{R}$ & Fever, angina [14] \\
\hline $\begin{array}{l}\text { Chrysactinia mexicana } \\
\text { Gray }\end{array}$ & 024102 & Compositae & $\mathrm{L}, \mathrm{F}, \mathrm{R}$ & $\begin{array}{l}\text { Respiratory affections [15], against coldness of the } \\
\text { spleen, tonic [4] }\end{array}$ \\
\hline $\begin{array}{l}\text { Clematis drummondii } \\
\text { T\&G. }\end{array}$ & 024164 & Ranunculaceae & L-S & $\begin{array}{l}\text { Disinfectant, antibiotic, }[4,15] \text {, psoriasis, seborrhea, } \\
\text { dermatitis, grains, freckles }[4]\end{array}$ \\
\hline Colubrina greggii Wats. & 024169 & Rhamanceae & $\mathrm{L}, \mathrm{F}, \mathrm{R}$ & Fever, antibiotic [16], cough, tuberculosis [17] \\
\hline Cordia boissieri A. DC. & 024167 & Borraginaceae & $\mathrm{F}$ & Cough, tuberculosis, respiratory affections $[4,15]$ \\
\hline Cyperus alternifolius L. & 024101 & Cyperaceae & L-S, R & Aphrodisiac, stimulating [18] \\
\hline Eupatorium odoratum L. & 024100 & Compositae & $\mathrm{L}, \mathrm{F}, \mathrm{R}$ & Chest complaints, pulmonary affections [15] \\
\hline $\begin{array}{l}\text { Heliotropium } \\
\text { angiospermum Murr }\end{array}$ & 024172 & Borraginaceae & L, F-S & Cough, anticatharral [17] \\
\hline $\begin{array}{l}\text { Leucophyllum frutescens } \\
\text { (Berl.) I.M.Johnst. }\end{array}$ & 024165 & Escrophulariaceae & $\mathrm{F}$ & $\begin{array}{l}\text { Tuberculosis, bronchitis, diarrhea, damage of the liver, } \\
\text { jaundice, fever [4]. }\end{array}$ \\
\hline $\begin{array}{l}\text { Phyla nodiflora (L.) } \\
\text { Greene. }\end{array}$ & 024168 & Verbenaceae & $\mathrm{L}, \mathrm{R}$ & Antibacterial, diuretic, emmenagogue, parasitic [19] \\
\hline Porlieria angustifolia & 024173 & Zigophylaceae & $\mathrm{L}, \mathrm{R}$ & $\begin{array}{l}\text { Tuberculosis, cough, cold, rheumatism, fall of hair, } \\
\text { venereal diseases [4] }\end{array}$ \\
\hline Rivinia humilis L. & 024170 & Phytolacaceae & L, F-Fr, R & $\begin{array}{l}\text { Dermatological [20], against } P \text {. aeruginosa, } K \text {. } \\
\text { pneumoniae and S. aureus }[21]\end{array}$ \\
\hline Salvia chia Fernald & 024103 & Labiatae & $\mathrm{L}, \mathrm{F}, \mathrm{R}$ & Antioxidant, pharyngitis $[18,22]$ \\
\hline Salvia coccinea Murr & 024096 & Labiatae & $\mathrm{L}, \mathrm{R}$ & Tonsillitis, antimicrobial $[18,22]$ \\
\hline Salvia reflexa Hornem & 024095 & Labiatae & $\mathrm{L}, \mathrm{F}$ & $\begin{array}{l}\text { Antioxidant, pharyngitis, tonsillitis, antimicrobial } \\
{[18,22]}\end{array}$ \\
\hline Schinus molle L. & 024166 & Anacardiaceae & L, F, B & Pus, helps to eyes, teeth and mouth $[4,23]$ \\
\hline Scutellaria ellptica Muhl & 024104 & Labiatae & L-S, F, R & Cough, expectorant, fever, cold [8] \\
\hline
\end{tabular}

L: leaves; F: flowers; B: bark; R: root; S: stem; Fr: fruit.

\section{Results}

This article describes the antimicrobial and antioxidant activities of plants used in traditional medicine in northeast Mexico. A total of 39 extracts from 17 different plants species belonging to 11 families were tested. In Table 1, the botanical name, voucher specimen, part used, popular use and some chemotaxonomic criteria of the selected plant species are shown.

3.1. Antimicrobial Activity. The results of the extracts displaying antimicrobial activity are shown in Table 2. No activity against Gram-negative bacteria ( $P$. aeruginosa, $\mathrm{K}$. pneumoniae and A. baumannii) was observed. The extracts from Ceanothus coeruleus (flowers), C. boissieri (flowers), Cyperus alternifolius (leaves, stem and root) and Schinus molle (leaves, flowers and bark) displayed the strongest activity against both sensitive and resistant $S$. aureus strains (Figure 1, MIC between 62.5 and $250 \mu \mathrm{g} \mathrm{ml}^{-1}$ ), the flower extracts from C. boissieri and Schinus molle were the most active. Five extracts belonging to Colubrine greggii (leaves and flowers), Cyperus alternifolius (root) and Schinus molle (bark) displayed the strongest activity against E. faecalis (MIC between 125 and $250 \mu \mathrm{g} \mathrm{ml}^{-1}$ ).

Most of the extracts tested exhibited some activity against C. glabrata (MIC ranged between 31.25 and $1000 \mu \mathrm{g} \mathrm{ml}^{-1}$ ).

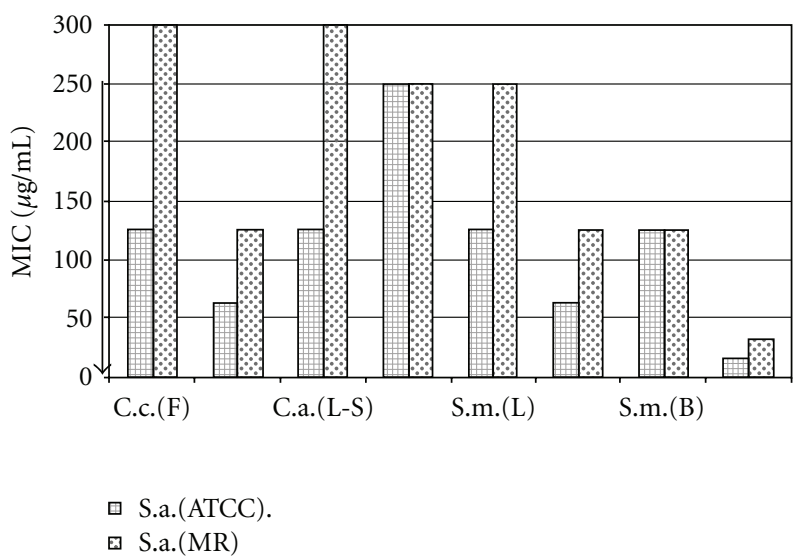

Figure 1: MIC of active extracts against S.a. Staphylococcus aureus strains: (ATCC) and an oxacillin-resistant strain (MR). L: leaves; F: flowers; R: root; L-S: leaves-steam; B: bark; C.c., Ceanothus coeruleus; C.m., Chrysactinia mexicana; C.g., Colubrina greggii; C.b., Cordia boissieri; C.a. Cyperus alternifolius; S.m., Schinus molle; Ctrl, control. The arrow shows better activity.

All test microorganisms were more sensitive to the extracts obtained from Ceanothus coeruleus (leaves and root), Colubrina greggii (leaves, stem and roots) and Schinus molle (leaves and flowers) (Table 2). 
TABLE 2: Antimicrobial activity of extracts against bacterial strains and yeast isolates tested using on microdilution assay.

\begin{tabular}{|c|c|c|c|c|c|c|c|c|c|c|c|}
\hline Plant & Part & $\begin{array}{c}\text { S. } a . \\
\text { ATCC }\end{array}$ & $\begin{array}{l}\text { S. } a . \\
\text { Rsist. }\end{array}$ & E.f. & $\begin{array}{l}\text { C. } a . \\
498\end{array}$ & $\begin{array}{c}\text { C. } a . \\
53\end{array}$ & $\begin{array}{l}\text { C. } a . \\
501\end{array}$ & $\begin{array}{c}\text { C. } g . \\
84\end{array}$ & $\begin{array}{l}\text { C.t. } \\
166\end{array}$ & $\begin{array}{c}C . k . \\
168\end{array}$ & $\begin{array}{c}\text { C. } p . \\
96\end{array}$ \\
\hline \multirow[t]{3}{*}{ Ceanothus coeruleus } & $\mathrm{L}$ & - & 1000 & - & 62.5 & 250 & 125 & 31.25 & 250 & 62.5 & 62.5 \\
\hline & $\mathrm{F}$ & 125 & - & - & 1000 & 1000 & - & 31.25 & 1000 & 1000 & 125 \\
\hline & $\mathrm{R}$ & - & 1000 & - & 125 & 31.25 & 31.25 & 31.25 & 250 & 125 & 31.25 \\
\hline \multirow[t]{3}{*}{ Chrysactinia mexicana } & $\mathrm{L}$ & 1000 & - & - & - & - & - & 31.25 & - & - & - \\
\hline & $\mathrm{F}$ & 1000 & - & - & - & - & - & 31.25 & 1000 & - & - \\
\hline & $\mathrm{R}$ & 1000 & - & - & - & - & - & 31.25 & - & - & - \\
\hline \multirow[t]{3}{*}{ Colubrina greggii. } & $\mathrm{L}$ & 1000 & - & 250 & 250 & 125 & 250 & 31.25 & 500 & 125 & 62.5 \\
\hline & $\mathrm{F}$ & 1000 & - & 250 & 250 & 125 & 250 & 31.25 & 500 & 125 & 125 \\
\hline & $\mathrm{R}$ & - & - & - & 250 & 250 & 125 & 31.25 & 500 & 1000 & 500 \\
\hline Cordia boissieri & $\mathrm{F}$ & 62.5 & 125 & - & - & - & - & 125 & - & - & - \\
\hline \multirow[t]{2}{*}{ Cyperus alternifolius } & L-S & 125 & - & 1000 & 500 & 1000 & 500 & 31.25 & 1000 & - & 1000 \\
\hline & $\mathrm{R}$ & 250 & 250 & 125 & 500 & 1000 & 500 & 31.25 & 500 & 500 & 1000 \\
\hline \multirow[t]{3}{*}{ Schinus molle } & $\mathrm{L}$ & 125 & 250 & 1000 & 125 & 125 & 125 & 31.25 & 500 & 500 & 250 \\
\hline & $\mathrm{F}$ & 62.5 & 125 & 1000 & 62.5 & 62.5 & 125 & 31.25 & 250 & 62.5 & 62.5 \\
\hline & B & 125 & 125 & 125 & 250 & 500 & 250 & 62.5 & 125 & 1000 & 1000 \\
\hline Cephalotin & & 15.6 & 31.25 & 31.25 & & & & & & & \\
\hline Fluconazole & & & & & 4 & 4 & 4 & 8 & 0.5 & 31.25 & 1 \\
\hline
\end{tabular}

MIC values in $\mu \mathrm{g} \mathrm{ml}^{-1}$; MIC > $1000 \mu \mathrm{g} \mathrm{ml}^{-1}$; L: leaves; F: flowers; B: bark; R: root; S: stem; S. a. Staphylococcus aureus; E. f. Enterococcus, faecalis; C. a. Candida albicans; C. g. Candida glabrata; C. t. Candida tropicalis; C. k. Candida krusei; C. p. Candida parapsilosis.

3.2. Antioxidant Activity. To test their antioxidant activity, all the extracts were analyzed by a DPPH free radical assay using TLC. Only 12 extracts displayed a strong antioxidant activity on the chromatographic plate: Ceanothus coeruleus (leaves, flowers and root), Chrysanctinia mexicana (leaves), Colubrina greggii (leaves, flowers and root), Cyperus alternifolius (root), Heliotropium angiospermum (flowers and leavesstem), Phyla nodiflora (leaves) and Schinus molle (bark). Smaller spots or spots with less intensity were displayed by three other extracts: Cordia boissieri (flowers), Chrysanctinia mexicana (flowers) and Schinus molle (flowers). The 15 active extracts were further tested for their scavenging activity using a DPPH spectrophotometric assay. The percentage reduction of DPPH radical exhibited by the different concentrations of each extract was calculated and subsequently its $\mathrm{EC}_{50}$ was determined (Table 3). Methanolic extracts from Ceanothus coeruleus (leaves and root), Chrysanctinia mexicana (flowers), Colubrina greggii (root), Cyperus alternifolius (root) and Schinus molle (bark), exhibited remarkable antioxidant activity with $\mathrm{EC}_{50}$ s less than $10 \mu \mathrm{g} \mathrm{ml}^{-1}$, while eight extracts displayed good antioxidant activities between 10.5 and $35.2 \mu \mathrm{g} \mathrm{ml}^{-1}$. Quercetin was used only as a positive control for the antioxidant activity assay. The $\mathrm{EC}_{50}$ for quercetin was $3.0 \mu \mathrm{g} \mathrm{ml}^{-1}(8.9 \mu \mathrm{M})$, similar to the result reported by Torres et al. [26].

\section{Discussion}

The results of our investigation confirmed the rationale for the medicinal use of some of the studied plants. The plants were selected according to their popular use, and in few cases, chemotaxonomic criteria were used (Table 1).

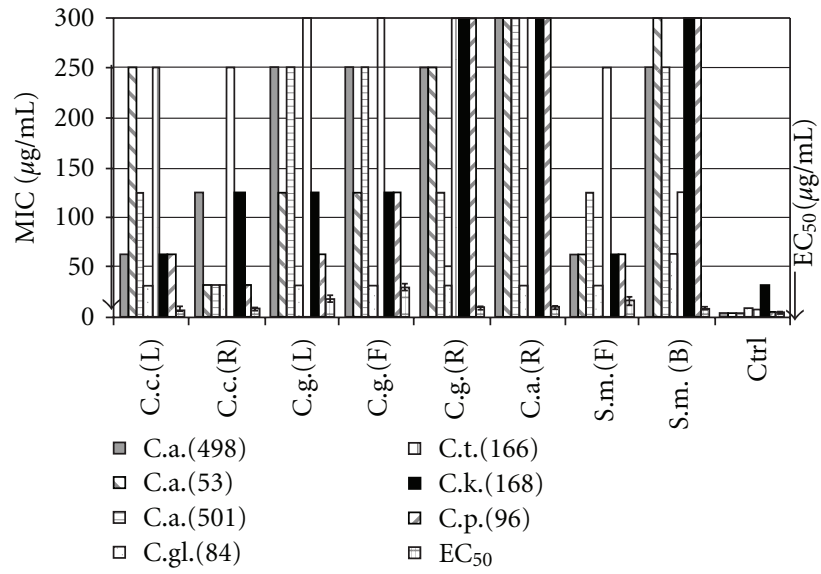

FIGURE 2: MIC of extracts active against yeast, and their antioxidant activity expressed as effective concentration $\left(\mathrm{CE}_{50}\right)$. L: leaves; F: flowers; R: root; L-S: leaves-steam; B: bark; C.c., Ceanothus coeruleus; C.m., Chrysactinia mexicana; C.g., Colubrina greggii; C.b., Cordia boissieri; C.a. Cyperus alternifolius; S.m., Schinus molle; Ctrl, control; C.a., Candida albicans; C.gl., Candida glabrata; C.t., Candida tropicalis; C.p., Candida parapsilosis. The arrow shows better activity.

The first remarkable aspect of the results obtained, was that no one of the extracts inhibited the growth of Gramnegative bacteria at the highest concentration tested. This lack of activity against Gram-negative bacteria is consistent with results discussed by other research groups [12]. In contrast, nine extracts obtained from five plants exhibited good or moderate activity against Gram-positive bacteria. 
TABLE 3: Effects of extracts and positive control on the in vitro free radical (DPPH) scavenging activity $\left(\mu \mathrm{g} \mathrm{ml}^{-1}\right)$.

\begin{tabular}{lcc}
\hline Plant & Part & $\mathrm{CE}_{50}\left(\mu \mathrm{g} \mathrm{ml}^{-1}\right)$ \\
\hline Ceanothus coeruleus & $\mathrm{L}$ & $8.3 \pm 1.0$ \\
& $\mathrm{~F}$ & $28.0 \pm 3.0$ \\
Chrysactinia mexicana & $\mathrm{R}$ & $5.6 \pm 2.9$ \\
& $\mathrm{~L}$ & $10.5 \pm 1.1$ \\
Colubrina greggii & $\mathrm{F}$ & $8.3 \pm 1.0$ \\
& $\mathrm{~L}$ & $18.3 \pm 3.2$ \\
Cordia boissieri & $\mathrm{F}$ & $29.0 \pm 3.7$ \\
Cyperus alternifolius & $\mathrm{R}$ & $7.9 \pm 1.7$ \\
Heliotropium angiospermum & $\mathrm{F}$ & $105.1 \pm 2.3$ \\
& $\mathrm{R}$ & $9.3 \pm 0.6$ \\
Phyla nodiflora & $\mathrm{F}$ & $35.2 \pm 2.1$ \\
Schinus molle & $\mathrm{L}-\mathrm{S}$ & $29.4 \pm 1.4$ \\
& $\mathrm{~L}$ & $20.8 \pm 2.21$ \\
Quercetin (positive control) & $\mathrm{F}$ & $15.2 \pm 4.0$ \\
\hline
\end{tabular}

L: leaves; F: flowers; B: bark; R: root; S: stem.

These extracts displayed also excellent activity against at least one of the yeast under evaluation (Table 3 ).

Some of the results obtained are consistent with those reported by other authors such as the antibacterial activity of Schinus molle $[8,16,27,28]$ and the antioxidant activity of H. angiospermum [29].

In the present study, we demonstrated for the first time that the flowers from Ceanothus coeruleus are active against an antibiotic-sensitive $S$. aureus strain, as well as against $C$. glabrata and C. parapsilosis; the leaves and root extracts had significant activity against all tested yeasts; moreover, all the extracts from this plant exhibited a remarkable antioxidant activity $\left(\mathrm{EC}_{50}\right.$ between 5.6 and $28 \mu \mathrm{g} \mathrm{ml}^{-1}$ ). We could not find any previous report regarding antioxidant activity of this species.

Leaves and flowers extracts from Chrysanctinia mexicana displayed a very potent antioxidant activity $\left(\mathrm{EC}_{50} 10.5\right.$ and $8.3 \mu \mathrm{g} \mathrm{ml}^{-1}$, resp.), as well as antifungal activity against $C$. glabrata (MIC $31.25 \mu \mathrm{g} \mathrm{ml}^{-1}$ ). We could not find any report regarding activity against yeast or antioxidant activity from Chrysanctinia mexicana or other species belonging to the same species.

The leaves and flowers extracts from Colubrina greggii showed inhibitory activity against $E$. faecalis (MIC $250 \mu \mathrm{g} \mathrm{ml}^{-1}$ ). The DPPH assay demonstrated highly potent antioxidant activity of leaves, flowers and roots from this plant $\left(\mathrm{EC}_{50}\right.$ between 7.9 and $\left.29 \mu \mathrm{g} \mathrm{ml}^{-1}\right)$. There were hitherto no reports regarding the antioxidant activity of any species from the Colubrina genus.

The root and leaf-stem extracts from Cyperus alternifolius showed a moderate activity against all yeasts tested, while the root extract produced a clear antioxidant activity $\left(\mathrm{EC}_{50} 9.3 \mu \mathrm{g} \mathrm{ml}^{-1}\right.$ ).

In summary, we conclude that most of the results of this study are in good agreement with the traditional uses of the investigated plants. All the extracts were active against C. glabrata. It appears that this isolate is sensitive to all the extracts used. Nine extracts showed activity against the rest of the yeasts tested; from these, eight extracts resulted with antioxidant activity (Figure 2 ). The root extract from Ceanothus coeruleus, displayed the greatest activity against yeast as well as the best antioxidant activity. Seven (46.6\%) of the 15 extracts that showed antioxidant activity, displayed antibacterial activity as well, and nine (80\%) resulted active against yeast.

Belofsky et al. [30] demonstrated an increase in the antimicrobial activity of pure compounds when they are combined with antioxidants. Therefore, we consider that if both antimicrobial and antioxidant compounds exist in the extracts, they could interact and enhance the antimicrobial activity. The bioassay-guided fractionation of these extracts in order to isolate and identify the compounds responsible for each of these activities, followed by a study of their interaction, is highly desirable.

\section{Funding}

Grant 103.5/06/0135 from PROMEP-México; U.A.N.L. (PAICYT) SA-1425-06.

\section{Acknowledgments}

The authors are grateful to traditional healers Milagro Aguirre and Angélica García and the biologist Humberto Sánchez Vega for helping in collection and identification of the plants, as well as to Marco Antonio Guzmán Lucio and M.C. María del Consuelo González de la Rosa for final taxonomic identification of all the species reported here. Ivonne Carrera is acknowledged for her technical assistance in the extraction procedure.

\section{References}

[1] R. A. A. Mothana, S. A. A. Abdo, S. Hasson, F. M. N. Althawab, S. A. Z. Alaghbari, and U. Lindequist, "Antimicrobial, antioxidant and cytotoxic activities and phytochemical screening of some Yemeni medicinal plants," Evidence-Based Complementary and Alternative Medicine, vol. 7, no. 3, pp. 323-330, 2010.

[2] V. Mulabagal, S. Van Nocker, D. L. Dewitt, and M. G. Nair, "Cultivars of apple fruits that are not marketed with potential for anthocyanin production," Journal of Agricultural and Food Chemistry, vol. 55, no. 20, pp. 8165-8169, 2007.

[3] S. J. Leu, Y. P. Lin, R. D. Lin et al., "Phenolic constituents of Malus doumeri var. formosana in the field of skin care," Biological and Pharmaceutical Bulletin, vol. 29, no. 4, pp. 740745, 2006.

[4] J. Adame and H. Adame, Plantas Curativas del Noreste Mexicano, Editorial Castillo, Nuevo León, Mexico, 2000.

[5] V. Schulz, R. Hänsel, M. Blumenthal, and V. E. Tyler, Rational Phytotherapy. A Reference Guide for Physicians and Pharmacists, Springer, Berlin, Germany, 2004.

[6] N. Waksman de Torres and A. Piñeyro-López, "Chemistry, structure and biological activity of Anthracenones of the Karwinskia genus," in Studies in Natural Products Chemistry, 
A. U. Rahman, Ed., pp. 555-606, Elsevier, Amsterdam, The Netherlands, 2000.

[7] A. Pérez, M. Orozco, V. Rivas, and N. Waksman, "Experimental design to determine the factors affecting the preparation or extracts for antibacterial use," Natural Product Communications, vol. 3, pp. 363-368, 2008.

[8] G. M. Molina-Salinas, A. Pérez-López, P. Becerril-Montes, R. Salazar-Aranda, S. Said-Fernández, and N. W. D. Torres, "Evaluation of the flora of Northern Mexico for in vitro antimicrobial and antituberculosis activity," Journal of Ethnopharmacology, vol. 109, no. 3, pp. 435-441, 2007.

[9] B. A. Alanís-Garza, G. M. González-González, R. SalazarAranda, N. Waksman de Torres, and V. M. Rivas-Galindo, "Screening of antifungal activity of plants from the northeast of Mexico," Journal of Ethnopharmacology, vol. 114, no. 3, pp. 468-471, 2007.

[10] R. Salazar, M. E. Pozos, P. Cordero, J. Perez, M. C. Salinas, and N. Waksman, "Determination of the antioxidant activity of plants from northeast Mexico," Pharmaceutical Biology, vol. 46, no. 3, pp. 166-170, 2008.

[11] L. A. Mitscher, “Coevolution: mankind and microbes," Journal of Natural Products, vol. 71, no. 3, pp. 497-509, 2008.

[12] L. M. Jarvis, "Imminent threat," Chemical and Engineering News, vol. 86, no. 15, pp. 22-24, 2008.

[13] A. T. Hoye, J. E. Davoren, P. Wipf, M. P. Fink, and V. E. Kagan, "Targeting mitochondria," Accounts of Chemical Research, vol. 41, no. 1, pp. 87-97, 2008.

[14] J. L. Díaz, Uso de las plantas medicinales de México. Monografías científicas II, Instituto Mexicano para el estudio de las plantas medicinales AC, Mexico City, Mexico, 1976.

[15] C. L. Cantrell, N. H. Fischer, L. Urbatsch, M. S. McGuire, and S. G. Franzblau, "Antimycobacterial crude plant extracts from South, Central, and North America," Phytomedicine, vol. 5, no. 2, pp. 137-145, 1998.

[16] G. Schmourlo, R. R. Mendonça-Filho, C. S. Alviano, and S. S. Costa, "Screening of antifungal agents using ethanol precipitation and bioautography of medicinal and food plants," Journal of Ethnopharmacology, vol. 96, no. 3, pp. 563-568, 2005.

[17] R. M. Mendieta and S. Del Amo, Plantas medicinales del Estado de Yucatán, Editorial Continental, Veracruz, Mexico, 1981.

[18] W. C. Evans, Trease \& Evans_Pharmacognosy, WB Sanders, London, UK, 2002.

[19] J. A. Duke and E. S. Ayensu, Medicinal Plants of China, Reference Publications, Algonac, Mich, USA, 1985.

[20] A. Ankli, M. Heinrich, P. Bork et al., "Yucatec Mayan medicinal plants: evaluation based on indigenous uses," Journal of Ethnopharmacology, vol. 79, no. 1, pp. 43-52, 2002.

[21] A. Salvat, L. Antonnacci, R. H. Fortunato, E. Y. Suarez, and H. M. Godoy, "Screening of some plants from Northern Argentina for their antimicrobial activity," Letters in Applied Microbiology, vol. 32, no. 5, pp. 293-297, 2001.

[22] R. C. Wren, Nueva enciclopedia de medicina herbolaria $y$ propiedades botánicas, Editorial Grijalbo, Barcelona, Spain, 1994.

[23] M. Gundidza, "Antimicrobial activity of essential oil from Schinus molle Linn," Central African Journal of Medicine, vol. 39, no. 11, pp. 231-234, 1993.

[24] "Performance standards for antimicrobial susceptibility testing," in Proceedings of the 12th informational Supplement M100-S12, National Committee for Clinical Laboratory Standards (NCCLS), Wayne, Pa, USA, 2002.
[25] Reference Method for Broth Dilution Antifungal Susceptibility Testing of Yeast, Approved Standard, Document M27A2. National Committee for Clinical Laboratory Standards (NCCLS), Wayne, Pa, USA, 2002.

[26] R. Torres, F. Faini, B. Modak, F. Urbina, C. Labbé, and J. Guerrero, "Antioxidant activity of coumarins and flavonols from the resinous exudate of Haplopappus multifolius," Phytochemistry, vol. 67, no. 10, pp. 984-987, 2006.

[27] M. Gundidza, "Antimicrobial activity of essential oil from Schinus molle Linn," Central African Journal of Medicine, vol. 39, no. 11, pp. 231-234, 1993.

[28] A. Dikshit, A. A. Nanqvi, and A. Husain, "Schinus molle: a new source of natural fungitoxicant," Applied and Environmental Microbiology, vol. 51, no. 5, pp. 1085-1088, 1986.

[29] A. Sánchez, K. García, F. May, and L. M. Peña, "Evaluation of biological activity of crude extracts from plants used in Yucatecan traditional medicine part I. Antioxidant, antimicrobial and beta-glucosidase inhibition activities," Phytomedicine, vol. 8, pp. 144-152, 2001.

[30] G. Belofsky, D. Percivill, K. Lewis, G. P. Tegos, and J. Ekart, "Phenolic metabolites of Dalea versicolor that enhance antibiotic activity against model pathogenic bacteria," Journal of Natural Products, vol. 67, no. 3, pp. 481-484, 2004. 


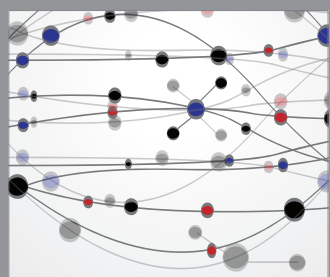

The Scientific World Journal
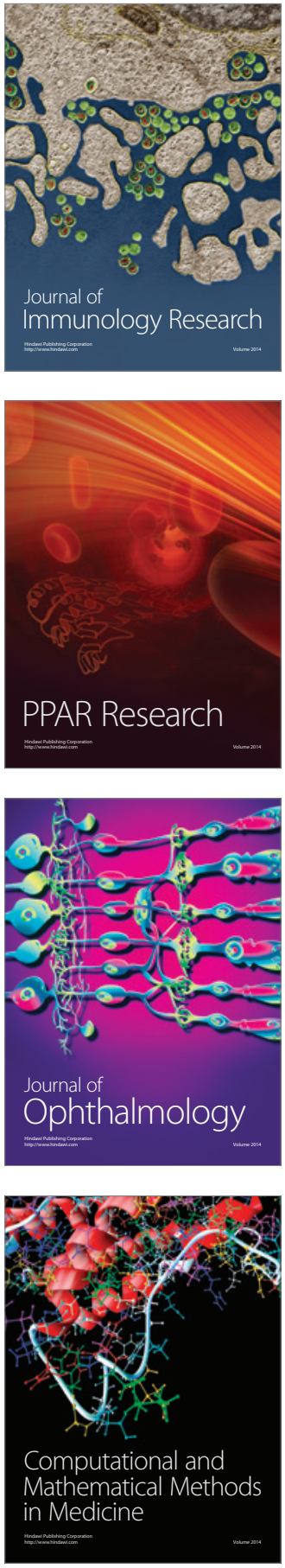

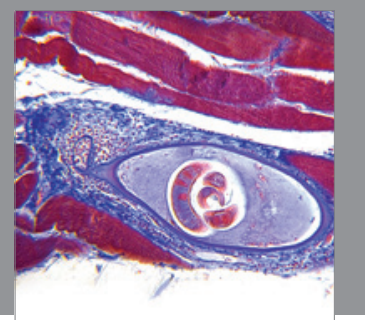

Gastroenterology

Research and Practice
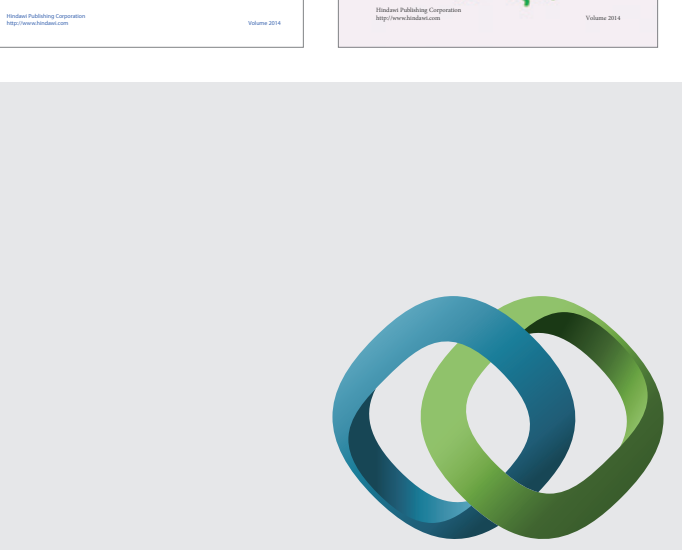

\section{Hindawi}

Submit your manuscripts at

http://www.hindawi.com
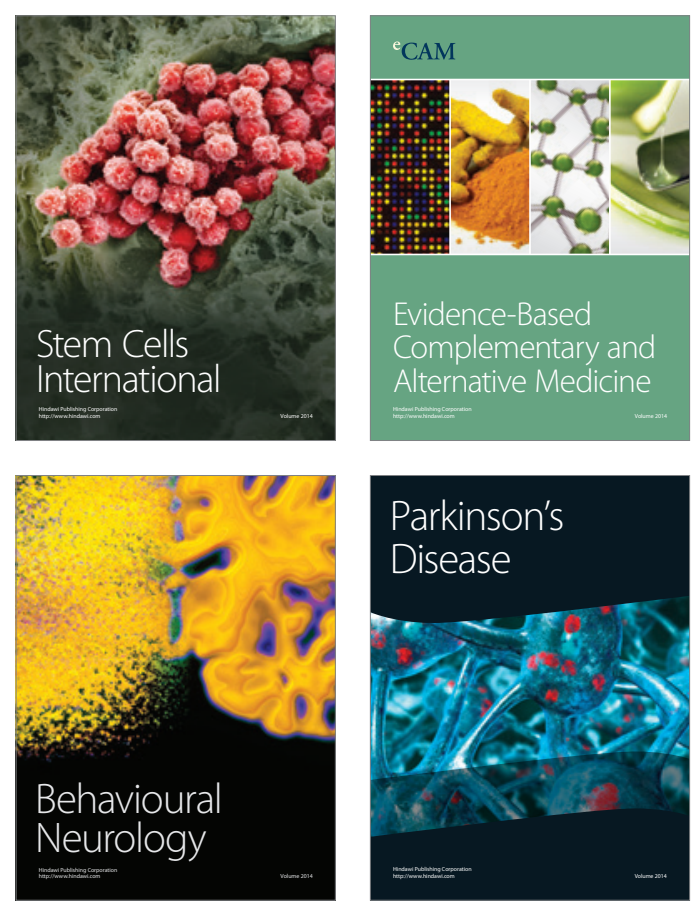

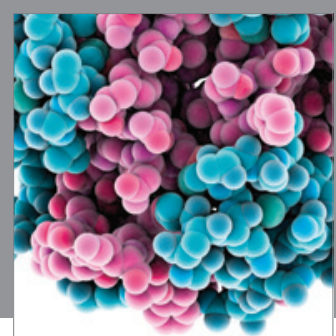

Journal of
Diabetes Research

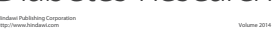

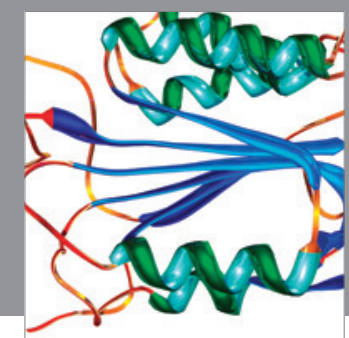

Disease Markers
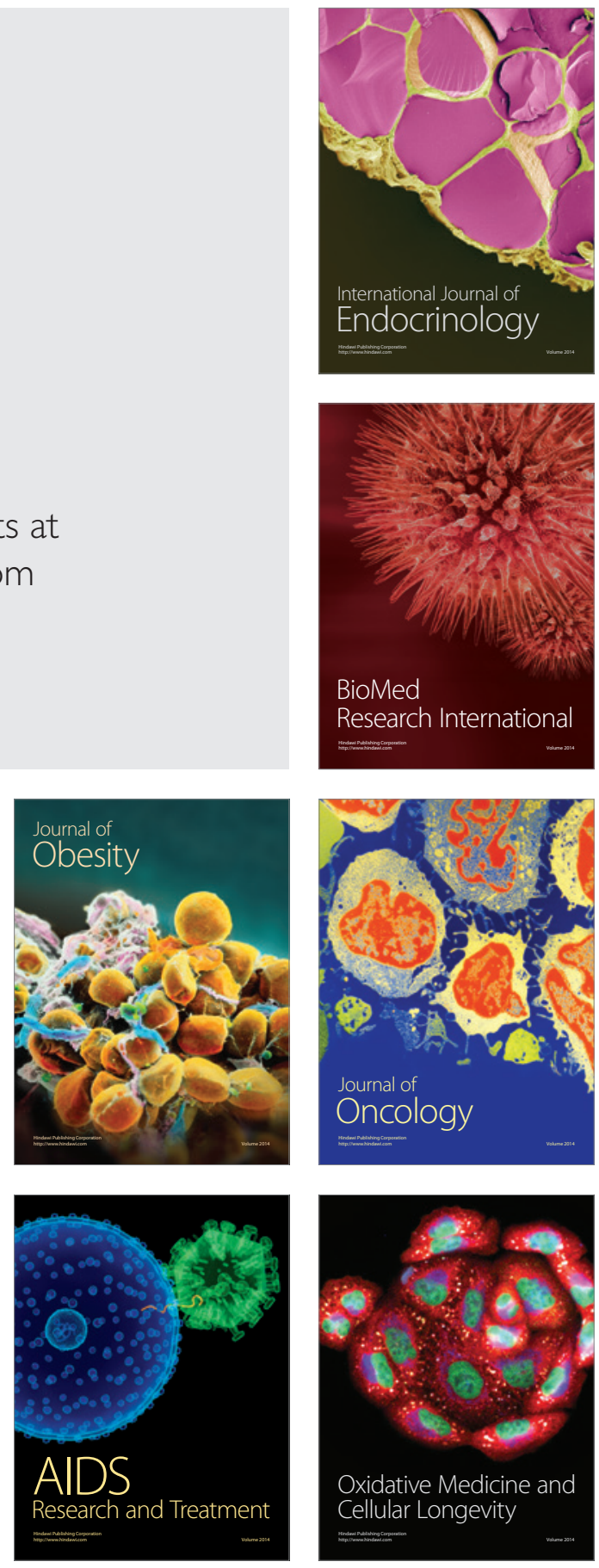